\title{
Manajemen Public Relations dalam Sosialisasi Program Pemberian Insentif Guru Ngaji
}

\author{
Nisa Robiah ${ }^{1 *}$, Yusuf Zaenal Abidin ${ }^{2}$, Dyah Rahmi Astuti ${ }^{1}$ \\ 1Jurusan Ilmu Komunikasi Humas, Fakultas Dakwah dan Komunikasi, UIN Sunan Gunung \\ Djati, Bandung \\ 2Jurusan Manajemen Dakwah, Fakultas Dakwah dan Komunikasi, UIN Sunan Gunung Djati, \\ Bandung \\ *Email : niisa.robiab@gmail.com
}

\begin{abstract}
ABSTRAK
Penelitian ini bertujuan untuk menggambarkan manajemen public relations yang dilakukan Dinas Pendidikan Kota Cimahi dalam mensosialisasikan program pemberian insentif guru ngaji. Metode penelitian yang digunakan yakni metode deskriptif. Peneliti mendeskripsikan fenomena yang diteliti berdasarkan data dari informan yaitu Dinas Pendidikan Kota Cimahi. Hasil penelitian menunjukkan bahwa manajemen public relations yang dilakukan Disdik Cimahi dalam sosialisasi program pemberian insentif guru ngaji diawali dengan tahap (1) pencarian data (fact finding) meliputi a) analisis program dan b) analisis khalayak. Tahap (2) perencanaan meliputi a) penetapan tujuan, b) menyusun kerangka acuan kerja $(\mathrm{KAK}), \mathrm{c})$ menetapkan target sasaran dan d) menyusun anggaran. Tahap (3) bertindak dan berkomunikasi meliputi a) penentuan sifat, tatanan dan jenis komunikasi, b) menyusun pesan sosialisasi dan c) menentukan komunikator sosialisasi. Tahap (4) yaitu evaluasi pada tingkat dampak/efek.
\end{abstract}

Kata Kunci: Manajemen public relations; insentif guru ngaji; Cimahi agamis

\section{ABSTRACT}

The research aims to describe socialization process which conducted by Cimahi Education Office in incentive religion teacher program. The research used descriptive method. The descriptions based on data obtained from informants, namely the Cimabi Education Office. The result showed public relations management by Cimabi Education Office in socialization of incentive religion teacher program, began stage (1) fact finding, covers a) program analysis, and b) public analysis. Stage (2) planning, covers a) set goals, b) formulate terms of reference, c) set targets and d) prepare budget. Stage (3) taking action and communicating, covers a) determine type of communication, b) compose message, and c) determine the communicator. Stage (4) evaluation, at level of impact.

Keywords: Public relations management; incentive religion teacher, Cimabi Agamis 


\section{PENDAHULUAN}

Manajemen public relations merupakan suatu proses perencanaan, hingga pengevaluasian suatu kegiatan komunikasi yang dinaungi oleh organisasi. Manajemen public relations dapat diimplementasikan di berbagai kegiatan pemerintahan. Kegiatan internal maupun eksternal pemerintahan tentunya tidak akan lepas dari komunikasi di dalamnya. Komunikasi dalam kegiatan pemerintah harus dikelola dengan baik melalui manajemen public relations karena merupakan salah satu kunci keberhasilan kegiatan tersebut. Kegiatan komunikasi di dalam pemerintahan yang harus dikelola dengan baik salah satunya yakni sosialisasi program kerja.

Sosialisasi merupakan suatu bentuk interaksi sosial yang bertujuan untuk memberikan informasi dan mempersuasi untuk merubah sikap seseorang. Sosialisasi dalam pemerintahan merupakan cara untuk menginformasikan kebijakan-kebijakan yang telah diputuskan oleh pemerintah kepada masyarakatnya. Sosialisasi juga berfungsi untuk menginformasikan programprogram kerja yang dimiliki oleh pemerintah dan mempersuasi masyarakat untuk berpartisipasi dalam program tersebut.

Patmawati dalam jurnal ilmu komunikasi volume 4 nomor 1 tahun 2016, menjelaskan bahwa sosialisasi pada kegiatan pemerintahan harus informatif. Proses sosialisasi yang informatif akan berkembang menjadi persuasi yang bertujuan untuk menarik minat, mengubah sikap, pendapat atau perilaku seseorang. Sosialisasi dalam pemerintahan merupakan bentuk komunikasi yang harus dilaksanakan untuk merealisasikan setiap program kerja, agar terlaksana dengan baik sesuai dengan rencana dan tujuan yang diharapkan.

Dinas Pendidikan Kota Cimahi merupakan instansi pemerintah yang saat ini memiliki program pendidikan keagamaan. Salah satu program pendidikan keagamaan yang diangkat dalam penelitian ini adalah program pemberian insentif kepada guru ngaji. Program ini merupakan bentuk perhatian khusus dari pemerintah terhadap guru ngaji yang memiliki peran besar dalam membentuk sumber daya manusia yang agamis. Seringkali guru ngaji ini luput dari perhatian pemerintah dan masyarakat sekitar.

Berdasarkan data pra wawancara bersama Bapak Nur Saleh (Kepala Seksi Pendidikan Masyarakat) pada Januari 2020, program pemberian insentif ini merupakan program yang sudah dilaksanakan di pemerintahan periode sebelumnya. Adapun pada tahun 2019 jumlah insentif yang diberikan jumlahnya lebih banyak dibandingkan dengan periode sebelumnya. Dana yang dianggarkan pada periode ini sebesar 3,4 miliar rupiah per tahun. Anggaran tersebut berdasarkan Dokumen Pelaksanaan Anggaran (DPA) tahun anggaran 2019 pada pendidikan non formal.

Anggaran dana yang ditambah pada periode ini tentunya bertujuan untuk 
memberikan apresiasi lebih dan mensejahterakan guru ngaji yang ada di kota Cimahi. Selama ini guru ngaji memiliki peranan penting dalam membina masyarakat di bidang keagamaan khususnya agama Islam. Pembinaan masyarakat dalam bidang keagamaan ini membantu mewujudkan visi Cimahi Kota Agamis dengan sumber daya manusia yang berakhlak mulia dan memiliki kecerdasan spiritual. Bedasarkan data pra penelitian yang didapatkan dari halaman website cimahi.go.id yang diakses pada Januari 2020, pada periode 2017-2020 kota Cimahi mengusung visi "Cimahi Baru, Maju, Agamis dan Berbudaya."

Harapan lainnya yaitu guru ngaji dapat membantu pemerintah meramaikan kembali masjid dan tempat belajar mengaji lainnya. Salah satunya dengan cara membudayakan kembali membaca dan mengkaji isi kandungan Al-Qur'an di lingkungan masyarakat. Lebih lanjutnya pemerintah dan masyarakat Cimahi dapat mengamalkan isi kandungan Al-Qur'an secara bertahap dan berkelanjutan. Hal tersebut diimplementasikan ketika melaksanakan kegiatan sehari-hari, kegiatan pemerintahan, pembangunan dan kemasyarakatan tidak lepas dari nilainilai keagamaan khususnya agama Islam.

Aktivitas sosialisasi pada program pemberian insentif guru ngaji sangat dibutuhkan untuk memberikan informasi dan mempersuasi guru ngaji untuk mencapai tujuan-tujuan dari program tersebut. Kegiatan tersebut tentunya harus didahului dengan perencanaan dan pengorganisasian dengan baik agar dapat mencapai tujuan-tujuan yang diharapkan.

Berdasarkan latar belakang yang telah dipaparkan, penelitian ini berfokus pada manajemen public relations yang dilakukan oleh Dinas Pendidikan Kota Cimahi dalam mensosialisasikan program pemberian insentif guru ngaji. Adapun pertanyaan penelitiannya yaitu, pertama bagaimana pencarian data (fact finding) sosialisasi program pemberian insentif guru ngaji oleh Dinas Pendidikan Kota Cimahi?. Kedua bagaimana perencanaan sosialisasi program pemberian insentif guru ngaji oleh Dinas Pendidikan Kota Cimahi. Ketiga bagaimana bertindak dan berkomunikasi dalam sosialisasi program pemberian insentif guru ngaji oleh Dinas Pendidikan Kota Cimahi?. Keempat Bagaimana evaluasi sosialisasi program pemberian insentif guru ngaji oleh Dinas Pendidikan Kota Cimahi?.

Penelitian terdahulu yang dilakukan oleh Maryamah pada tahun 2019 yang dilaporkan dalam bentuk skripsi dengan judul Sosialisasi Program Kangpisman Oleh Bidang Humas Pemerintah Kota Bandung Dalam Upaya Bandung Bersih menjadi salah satu rujukan untuk pengembangan ilmu di bidang komunikasi Humas. Penelitian tersebut membahas bagaimana pemerintah kota Bandung mensosialisasikan program Kangpisman melalui berbagai media konvensional dan online. Sosialisasi yang dilakukan oleh bagian Humas Kota Bandung, sedangkan dalam penelitian ini pelaksanaan dan sosialisasi program dilakukan oleh Dinas Pendidikan Kota Cimahi. 
Metode yang akan digunakan pada penelitian ini adalah metode deskriptif. Metode deskriptif digunakan karena dalam penelitian ini peneliti melaporkan dan memberikan gambaran tentang manajemen public relations yang dilakukan oleh Dinas Pendidikan Kota Cimahi dalam mensosialisasikan program pemberian insentif gutu ngaji. Peneliti menganalisis data-data penelitian yang didapatkan melalui wawancaran bersama tiga orang informan.

\section{LANDASAN TEORITIS}

Konsep yang digunakan dalam penelitian ini adalah konsep four steps public relations (PR) dari Cutlip, Center dan Broom. Konsep ini digunakan karena berdasarkan data penelitian tahapan-tahapan yang ada pada konsep ini relevan dengan tahapan yang dilakukan oleh Dinas Pendidikan Kota Cimahi dalam mensosialisasikan program pemberian insentif guru ngaji. Konsep manajemen PR ini menurut Hasybullah (2019: 54) merupakan suatu proses pengolahan pesan dari satu pihak kepada pihak lain untuk mencapai tujuan secara efektif dan efisien.

Manajemen PR sendiri merupakan salah satu fungsi PR sebagai manajemen. Menurut Putri (2018: 61) PR merupakan fungsi manajemen yang bertugas membangun hubungan baik antara organisasi dengan publiknya. Hubungan tersebut diawali dengan membangun komunikasi yang efektif sehingga timbul saling menerima, saling pengertian dan saling mendukung antara kedua belah pihak.

Konsep four steps PR menurut Morissan (2014: 108) terdiri dari empat tahapan pokok yang harus dilaksanakan, sebagai berikut:

\section{Pencarian Data (Fact Finding)}

Pencarian data (fact finding) merupakan cara untuk mendifinisikan masalah PR yang tengah dihadapi dengan dua hal yaitu analisis situasi dan riset atau penelitian PR.

Analisis situasi (situation analysis) diawali dengan kegiatan mengumpulkan seluruh data dan informasi mencakup latar belakang serta informasi mengenai pihak-pihak yang terlibat atau terpengaruh baik pihak internal maupun eksternal. Analisis faktor internal melingkupi tinjauan ulang secara menyeluruh terhadap persepsi dan tindakan dari aktor-aktor kunci yang ada di perusahaan. Analisis terhadap faktor eksternal pada prinsipnya melakukan tinjauan ulang secara sistematis terhadap latar belakang masalah yang berasal dari perusahaan. Tahap pengumpulan informasi ini merupakan tahap yang penting karena temuan yang diperoleh pada tahap ini akan memengaruhi tahap selanjutnya.

Public relations (PR) tidak dapat melaksanakan kegiatannya dengan berhasil dan efektif tanpa melakukan riset/penelitian terlebih dahulu. Menurut Morissan (2014: 125) riset PR dapat dibagi menjadi dua bagian berdasarkan metodenya, yaitu riset formal dan riset informal. Metode riset informal bermanfaat sebagai 
cara untuk mendeteksi adanya masalah atau situasi yang bermasalah (problem situation). Riset ini dapat dikategorikan sebagai riset pendahuluan (presenting research). Kelemahan metode riset informal terdapat pada penentuan sampel karena tidak menggunakan metode khusus, sehingga sampel atau responden yang dipilih menjadi tidak representatif.

Riset formal merupakan penelitian yang dilakukan secara sistematis. Menurut Morissan (2014: 136-144) model riset formal membantu praktisi PR menjawab pertanyaan mengenai masalah yang tidak dapat dijawab melalui riset informal. Metode riset formal ini hanya akan bermanfaat jika peneliti telah mendapat menentukan tujuan riset secara jelas. Sebelum menentukan suatu rancangan riset yang akan digunakan metode riset formal memungkinkan praktisi PR membuat pernyataan yang tepat mengenai khalayak PR berdasarkan data yang diperoleh dari responden yang dipilih dengan menggunakan metode ilmiah. Metode riset dapat dibagikan ke dalam empat jenis, yakni analisis data sekunder, (secondary analisis), survei, observasi, dan analisis isi.

\section{Perencanaan dan Pemrograman}

Penetapan rencana langkah-langkah yang diambil harus bertujuan menyelesaikan masalah yang ada pada perusahaan. Rencana disusun setelah praktisi PR mengetahui masalah yang sedang dihadapi, sedangkan masalah dapat diketahui dari hasil riset atau penelitian yang telah dilakukan di tahap pertama. Menurut Mukarom (2015: 198) untuk merencanakan program PR diperlukan beberapa langkah yaitu sebagai berikut:

Langkah pertama menetapkan tujuan menurut Morissan (2018: 167) yaitu menjelaskan hasil-hasil apa saja yang harus dicapai. Pada praktiknya, tujuan program harus memiliki fungsi yaitu: memberikan fokus dan arah bagi mereka yang sedang mengembangkan strategi dan taktik program, memberikan arahan dan motivasi bagi mereka yang ditugaskan melaksanakan program, dan mengemukakan hasil yang harus dicapai untuk memberikan arahan dalam hal pengawasan dan evaluasi program.

Langkah kedua membuat teori kerja bertujuan untuk membuat petunjuk mengenai apa yang harus dikerjakan guna mencapai hasil yang diharapkan. Menurut Morissan (2018: 159) petunjuk mengenai apa yang harus dikerjakan ini disebut dengan teori kerja. Teori kerja berfungsi untuk membimbing para pelaksana dalam menyiapkan program, menuliskan laporan, dan bagaimana hubungan yang harus terjalin. Teori kerja mewakili ide atau pandangan praktisi PR mengenai apa yang diharapkan terjadi.

Langkah ketiga menetapkan target khalayak, menurut Mukarom (2015: 198) menjadi salah satu sasaran program kerja PR. Sasaran tersebut harus jelas dan spesifik agar tujuan, strategi dan taktik yang dikerjakan dapat memberikan hasil yang optimal. Manajemen PR dalam hal ini mendapat kejelasan mengenai 
karakteristik setiap khalayaknya. Tanpa penentuan karakter yang jelas tidak akan banyak membantu praktisi PR dalam merencanakan program kerjanya.

Langkah keempat merancang anggaran menurut Mukarom (2015: 207) merupakan bahan bakar perencanaan yang telah disusun oleh praktisi PR. Rincian pembiayaan ini dilakukan untuk setiap komponen yang ada dalam rencana, misalnya biaya untuk sumber daya manusia, biaya perlengkapan biaya operasional dan biaya tak terduga. Kemampuan seorang praktisi PR dalam menyusun anggaran biaya dapat memberikan gambaran tentang kegiatankegiatan yang bisa dilakukan dan yang tidak bisa dilakukan, kegiatan yang lebih diutamakan dan kegiatan yang lebih dikesampingkan terlebih dahulu.

\section{Bertindak dan Berkomunikasi}

Tahap bertindak dan berkomunikasi atau implementasi mencakup tindakan apa saja yang akan dilakukan pesan apa saja yang ingin disampaikan dan jenis media yang akan digunakan untuk menyampaikan pesan yang dimaksud. Menurut Morissan (2015: 188) untuk menentukan tindakan dan komunikasi diperlukan beberapa langkah yaitu sebagai berikut:

Langkah pertama, menyusun komponen strategi komunikasi meliputi strategi tindakan yang merupakan penggerak utama program PR biasanya strategi ini bersifat abstrak atau tidak mudah dikenali oleh pihak luar. Menurut Mukarom (2015: 224) untuk mengimplementasikan strategi komunikasi ini manajer PR berkomunikasi dan melakukan beberapa hal sebagai berikut, yakni membingkai pesan, memiliki nilai berita, semiotika atau penggunaan tanda berkaitan dengan arti atau makna yang ingin disampaikan, menggunakan simbol dan stereotip.

Langkah kedua, proses penyebaran pesan yang dikirimkan harus benarbenar diarahkan dengan tingkat ketepatan yang tinggi agar mencapai sasarannya. Menurut Effendy (2003: 18) komunikator penyampain pesan harus mampu menyampaikan pesan dalam bahasa yang mudah dipahami dan dimengerti oleh penerimanya, sesuai dengan kebutuhan dan ketertarikan penerima pesan.

Langkah ketiga, menentukan teknik PR yang akan digunakan dalam implementasi rancangan kegiatan atau program PR. Tekniknya antara lain press release, kampanye, penerbitan buku khusus, pesan-pesan lisan (spoken words), dan identitas perusahaan (corporate identitiy).

\section{Evaluasi}

Tahap terakhir dalam empat langkah manajemen PR yakni pengevaluasian program. Evaluasi dapat dikatakan sebagai kegiatan menentukan nilai suatu program atau kegiatan. Evaluasi dalam program komunikasi kehumasan merupakan umpan balik dalam proses komunikasi. Dengan demikian evaluasi program kehumasan harus dilakukan berdasarkan data atau fakta bukan berdasarkan intuisi seseorang. Hasil evaluasi program kehumasan harus secara 
jelas memberikan gambaran tentang perubahan perilaku yang terjadi di masyarakat secara baik pengetahuan sikap maupun keterampilan.

Evaluasi tidak dapat dikatakan lengkap tanpa memberikan penilaian atas tiap-tiap tingkatan. Menurut Morissan (2015: 232) tingkatan evaluasi program PR yaitu pertama evaluasi tahap persiapan memberikan penilaian atas kualitas informasi dan kecukupan informasi serta perencanaan yang telah dilakukan. Kedua evaluasi tahap pelaksanaan menilai kelengkapan taktik dan cukupan usaha yang telah dilakukan. Ketiga evaluasi terhadap dampak memberikan penilaian atas efek yang dihasilkan dari suatu program kehumasan yang telah dilaksanakan.

\section{HASIL DAN PEMBAHASAN}

Dinas Pendidikan (Disdik) merupakan perangkat daerah kota Cimahi yang membantu Wali Kota melaksanakan urusan pemerintahan di bidang pendidikan. Disidik Cimahi beralamat di kantor Pemerintah Kota Cimahi Gedung B lantai 2 yang terletak di Jalan Raden Demang Hardjakusumah Blok Jati Cihanjuang Kelurahan Cibabat Kecamatan Cimahi Utrara Kota Cimahi Jawa Barat 40513. Dinas Pendidikan dipimpin oleh Kepala Dinas yang berkedudukan dan bertanggung jawab kepada Wali Kota melalui Sekretaris Daerah.

Disdik Cimahi memiliki program pendidikan keagamaan. Salah satu program pendidikan keagamaan yang diangkat dalam penelitian ini adalah program pemberian insentif guru ngaji. Program pemberian insentif guru ngaji kota Cimahi merupakan program pemerintah Cimahi dalam mewujudkan Cimahi Agamis, yang tertuang pada Visi Wali Kota Cimahi 2017-2022.

Hasil penelitian menunjukkan bahwa Disdik Cimahi melakukan empat tahapan dalam mensosialisasikan program pemberian insentif guru ngaji. Empat tahapan tersebut pertama tahap pencarian data (fact finding), kedua tahap perencanaan, ketiga tahap bertindak dan berkomunikasi, terakhir tahap evaluasi sosialisasi program pemberian insentif guru ngaji.

\section{Tahap Pencarian Data (Fact Finding)}

Pengumpulan data dan fakta merupakan tahap untuk mengetahui latar belakang dilaksanakannya sosialisasi program pemberian insentif guru ngaji di Kota Cimahi. Tahap pertama pada konsep manajemen public relations ini menurut Sulistyaningtyas (2010: 178) merupakan tahap yang akan menentukan keputusan-keputusan yang diambil pada tahap berikutnya. Kegiatannya berupa pengamatan dan penelitian terhadap publik internal maupun eksternal yang berkaitan dan memiliki kepentingan dengan program kerja yang dijalankan.

Pada tahap awal ini, data dan fakta yang menjadi dasar untuk mendefinisikan masalah humas dapat dikumpulkan melalui beberapa cara. Menurut Morissan (2018: 111) data dan fakta dapat dikumpulkan dengan dua cara. Kedua cara tersebut yakni dengan analisis program dan riset PR. 
Berdasarkan hasil wawancara dengan tiga orang informan secara daring (dalam jaringan) terkait tahap pencarian data sosialisasi program pemberian insentif guru ngaji, didapatkan dua klasifikasi sebagai berikut:

Pertama analisis program dilakukan untuk menjawab latar belakang dilaksanakannya sosialisasi dan pesan apa saja yang akan disampaikan pada saat sosialisasi. Hasil temuan peneliti tentang analisis program sebagai langkah awal pada tahap fact finding didapatkan tiga hal yang melatarbelakangi adanya sosialisasi program pemberian insentif guru ngaji. Pertama, program ini merupakan program prioritas Wali Kota dalam mewujudkan Cimahi Agamis. Kedua, merupakan upaya pemerintah untuk mensejahterakan guru ngaji. Ketiga, untuk mewujudkan Cimahi Agamis dengan membudayakan magrib mengaji.

Terdapat hal penting lainnya yang menjadi latar belakang dilaksanakannya sosaialisasi program insentif guru ngaji. Program ini merupakan program pemerintah, dimana program pemerintah pasti akan disosialisasikan. Karena target utama dari kegiatan pemerintahan adalah masyarakat. Pemerintah yang baik yakni pemerintah yang memiliki hubungan baik dengan masyarakatnya. Hal ini sesuai dengan yang diungkapkan oleh Hasan (2010: 23) dalam bukunya yang berjudul Komunikasi Pemerintahan dijelaskan bahwa suatu program pemerintah tidak akan berjalan dengan baik tanpa disosialisasikan kepada masyarakatnya.

Pesan sosialisasi dalam komunikasi pemerintahan merupakan hal penting karena termasuk ke dalam salah satu komponen komunikasi. Adapun yang dimaksud dengan pesan menurut Effendy (2003: 27) adalah setiap perkataan dan informasi yang diungkapkan oleh komunikator dengan memiliki satu inti tema. Pesan disampaikan dengan tujuan untuk merubah pemikiran dan sikap dari sasaran penerima pesan. Pesan dapat disampaikann secara verbal, baik secara lisan maupun tulisan, atau secara non verbal apabila penyampaian pesan dilakukan secara langsung tatap muka.

Mencari latar belakang dan memahami pesan apa yang akan disampaikan ketika sosialisasi merupakan langkah pertama yang ditempuh pada tahap fact finding dan termasuk ke dalam analisis situasi. Menurut Morissan (2018: 114) analisis situasi terdiri atas seluruh latar belakang dari rumusan masalah yang sudah disusun sebelumnya agar masalah tersebut tergambar lebih rinci. Analisis situasi harus memerhatikan faktor internal dan juga faktor eksternal.

Faktor internal yang menjadi perhatian dalam analisis situasi diantaranya yakni penjelasan atau gambaran mengenai produk, jasa atau suatu program kerja. Hal inilah yang dilakukan oleh Disdik, menganlisa terlebih dahulu program insentif guru ngaji yang akan dijelaskan pada saat sosialisasi. Hal apa saja yang melatarbelakangi pelaksanaan sosialisasi dan pesan apa saja yang harus disampaikan.

Kedua, langkah analisis khalayak. Hal ini dilakukan untuk mengetahui terlebih dahulu bagaimana kondisi khalayak yang menjadi sasaran program 
pendidikan keagamaan di Kota Cimahi. Analisis khalayak juga untuk mengetahui karakteristik dan latar belakang calon sasaran sosialisasi program pemberian insentif guru ngaji.

Hasil temuan di lapangan pada langkah analisis khalayak program pemberian insentif guru ngaji, didapatkan dua cara yang dilakukan untuk mengumpulkan data latar belakang dan karakteristiknya. Cara yang pertama yakni Disdik melakukan pendataan calon penerima insentif guru ngaji melalui Lurah dan RW. Data yang di dapatkan dari para pejabat setempat tersebut berupa form data isian biodata dari calon penerima insentif guru ngaji. Cara yang kedua, yakni Disidik membentuk tim khusus yang terjun langsung ke lapangan untuk mengamati secara langsung bagaimana kondisi dan karakteristik khalayak.

Langkah untuk mengetahui latar belakang dan karakteristik khalayak yang dilakukan oleh Disdik ini sebagai upaya agar komunikasi dalam bentuk sosialisasi dapat mencapai tujuan yang diharapkan serta minim hambatan. Khalayak disini dapat diartikan sebagai komunikan atau penerima pesan sosialisasi. Komunikan merupakan unsur komunikasi yang sangat penting dan harus diperhatikan dari segi kerangka pengetahuan (frame of reference) dan pengalamannya (field of experience). Kedua hal yang harus diperhatikan dari komunikan tersebut menjadi sangat penting karena akan menentukan strategi komunikasi yang digunakan oleh komunikator.

Komunikan menurut Effendy (2003: 30) adalah penerima pesan yang disampaikan oleh komunikator. Hal yang paling memengaruhi komunikan dalam menerima pesan dari komunikator adalah bidang pengalaman (field of experience) dan kerangka pemikiran (frame of reference). Apabila bidang pengalaman dan kerangka pemikiran yang dimiliki oleh komunikan sama dengan komunikator maka komunikasi akan berjalan lancar. Namun jika kedua hal tersebut bertolak belakang antara komunikan dengan komunikator maka komunikasi akan sukar untuk dijalani dan pesan akan lebih sulit diterima serta dicerna oleh komunikan.

Melakukan analisis terhadap khalayak yang dilakukan oleh Disdik ini sesuai dengan langkah analisis situasi faktor eksternal pada tahap fact finding dalam manajemen public relations program pemberian insentif guru ngaji. Menurut Mukarom (2015: 174) analisis faktor eksternal merupakan kajian secara terperinci terhadap pihak-pihak eksternal yang terlibat dan terpengaruh oleh program kerja. Sebagian besar kegiatan pada analisis situasi faktor eksternal ini yakni mengumpulkan informasi tentang pihak-pihak berkaitan tersebut.

Salah satu informasi yang dikumpulkan dalam langkah analisis faktor eksternal menurut Mukarom (2015: 175) dalam bukunya yang berjudul Manajemen Public relations Panduan Efektif Pengelolaan Hubungan Masyarakat 
adalah daftar orang-orang atau khalayak beserta latar belakangnya. Khalayak disini adalah pihak-pihak yang terkena langsung dengan program yang dibuat. Hal ini juga dilakukan oleh Disdik, mengumpulkan data dan informasi mengenai karakteristik dan latar belakang khalayak melalui pendataan oleh Lurah dan ketua RW serta dengan membentuk tim khusus yang mengamati secara langsung di lapangan.

\section{Tahap Perencanaan}

Perencanaan sosialisasi program merupakan tahap kedua yang ditempuh setelah tahap fact finding. Data dan fakta yang dikumpulkan pada tahap pertama menentukan dalam proses perencanaan. Perencanaan harus dikaji dengan matang karena berpengaruh besar pada keberhasilan program. Rencana yang disusun pada tahap ini bukan berdasarkan keinginan organisasi, tetapi berdasarkan pada data dan fakta yang dikumpulkan pada tahap pertama.

Terdapat beberapa langkah yang dilakukan pada tahap perencanaan, Morissan (2018: 152) menjelaskan langkah-langkah pada tahap merencanakan program humas diantaranya, manajemen strategis yang meliputi pengambilan keputusan mengenai sasaran dan tujuan program. Selanjutnya, pernyataan misi yang dapat diartikan menuliskan tujuan-tujuan yang ingin dicapai, dilanjutkan dengan menyusun teori kerja, menetapkan target khalayak, menyusun anggaran hingga tindakan ketika menghadapi situasi krisis.

Berdasarkan hasil wawancara dengan tiga orang informan, secara daring (dalam jaringan) terkait tahap perencanaan program pemberian insentif guru ngaji, didapatkan empat langkah sebagai berikut:

Pertama, menentukan tujuan yang ingin dicapai. Hal ini untuk menentukan arah yang dituju oleh Disdik Cimahi dan akan menentukan cara-cara yang ditempuh untuk mencapai tujuan-tujuan tersebut. Berdasarkan hasil temuan di lapangan, terdapat dua tujuan yang ingin dicapai dalam mensosialisasikna program insentif guru ngaji. Pertama, dengan adanya sosialisasi diharapkan dapat tersampaikannya tujuan dari program insentif guru ngaji itu sendiri.

Tujuan dari program insenif guru ngaji seperti yang dibahas sebelumnya, yakni untuk mewujudkan visi Cimahi Agamis melalui upaya membudayakan magrib mengaji. Dua hal tersebut didukung dengan mensejahetrakan guru ngaji melalui pemberian insentif yang diberikan setiap bulannya. Guru ngaji yang membantu menggerakkan masyarakat membudayakan magrib mengaji di wilayahnya masing-masing.

Tujuan sosialisasi yang kedua yakni membangun sinergitas antara Disdik dengan pejabat setempat tingkat Lurah dan RW. Sinergi antara ketiga pihak tersebut dibangun ketika Disdik membuthkan data calon penerima insentif. Disdik meminta bantuan Lurah dan RW untuk melakukan pendataan terhadap warganya yang berhak menerima insentif tersebut. Hal ini dilakukan agar 
program dapat tertuju tepat pada sasarannya karena pejabat setempat dirasa lebih mengetahui mana warganya yang berprofesi sebagai guru ngaji dan berhak menerima insentif.

Penetapan tujuan yang dilakukan oleh Disdik Cimahi sesuai dengan yang diungkapkan oleh Morissan (2018: 149) dalam bukunya yang berjudul Manajemen Public relations Startegi Menjadi Humas Profesional. Menurutnya, pada tahap perencanaan program Humas, langkah pertama yang harus dilakukan adalah menetapkan tujuan. Tujuan dirumuskan berdasarkan hasil dari riset pengumpulan data dan fakta pada tahap pertama (fact finding), dengan demikian penetapan tujuan dilakukan secara objektif tidak hanya berdasarkan perkiraan saja.

Kedua, merumuskan teori kerja sebagai petunjuk dan pedoman ketika melaksanakan program, sehingga dapat berhasil dan mencapai hasil yang diharapkan. Di dalam teori kerja menjelaskan pembagian tugas bagi setiap divisi yang bertugas menjalankan program, prosedur tentang kegiatan-kegiatan program, serta strategi yang akan digunakan.

Hasil temuan di lapangan yang didapatkan melalui wawancara dengan tiga orang informan, tentang perumusan teori kerja program insentif guru ngaji. Teori kerja yang ada pada program ini disebut dengan kerangka acuan kerja (KAK). KAK disusun oleh Seksi Pembinaan Pendidikan Manyarakat yang ditugaskan oleh Kepala Dinas untuk melaksanakan program tersebut. KAK ini berfungsi untuk membimbing para eksekutor ketika nanti melaksanakan program, sehingga tetap pada jalurnya dan sesuai dengan rencana pencapaian tujuan yang tertera di KAK tersebut. Secara singktanya, KAK ini merupakan pandangan atau rencana Disdik tentang pencapaian tujuan dari program insentif guru ngaji.

Berdasarkan hal tersebut, KAK yang dibuat oleh Disdik sesuai dengan yang dibahas oleh Morissan (2018: 159) dalam bukunya yang berjudul Manajemen Public relations Startegi Menjadi Humas Profesional. Menurutnya, salah satu langkah penting dalam tahap perencanaan yakni membuat teori kerja. Teori kerja dibuat berdasarkan tujuan-tujuan yang ingin dicapai. Acuan kerja yang disusun pada akhirnya untuk mencapai tujuan yang diharapkan tersebut.

Teori kerja berfungsi untuk membimbing ketika melaksanakan taktiktaktik untuk mencapai hasil yang diharapkan. Teori kerja dalam program insentif guru ngaji disebut kerangka acuan kerja (KAK), menurut Morisan (2018: 160) harus dinyatakan secara jelas ketika diformulasikan dalam bentuk tujuan atau sasaran yang ingin dicapai. Selain berfungsi sebagai acuan ketika melaksanakan program, teori kerja atau KAK ini nantinya akan menjadi indikator evaluasi antara perencanaan dengan pelaksanaan program.

Ketiga, menetapkan target sosialisasi. Sosialisasi merupakan kegiatan 
komunikasi yang bertujuan untuk merubah pengetahuan, sikap dan perilaku sasarannya sesuai dengan yang diharapkan. Sosialisasi merupakan kegiatan komunikasi tentu memiliki unsur-unsur yang sama dengan unsur-unsur komunikasi. Unsur-unsur tersebut penting adanya dalam proses komunikasi. Salah satu unsurnya yakni komunikan atau penerima pesan, dalam hal ini berarti sasaran sosialisasi.

Hasil temuan di lapangan yang didapatkan melalui wawancara secara daring (dalam jaringan) didapatkan dua publik yang menjadi sasaran pada sosialisai program pemberian insentif guru ngaji. Pertama, pejabat setempat tingkat Lurah dan RW yang menjadi tahap awal pendataan calon penerima insentif guru ngaji. Kedua adalah guru ngaji yang merupakan sasaran utama program pemberian insentif guru ngaji.

Sosialisasi penting disampaikan kepada Lurah dan RW yang melakukan pendataan awal penentuan calon penerima insentif guru ngaji. Lurah dan RW ini harus diberikan pemahaman dan harus selaras dalam melangkah menjalankan program pemberian insentif guru ngaji. Mereka harus mengetahui tugas, fungsi dan keterlibatan mereka dalam program ini agar dapat menjalannkanya dengan baik dan mencapai tujuan yang diharapkan.

Sasaran sosialisasi utama pada program ini yakni guru ngaji yang merupakan target utama penerima bantuan insentif guru ngaji. Inilah yang menjadi inti dalam rancangan sosialisasi. Sosialisasi dirancang agar program insentif guru ngaji ini dapat tersampaikan dengan baik, mengingat program ini berkaitan dengan program pendidikan keagamaan lainnya. Program tersebut yakni membudayakan magrib mengaji di wilayah kota.

Menetapkan sasaran sosialisasi program insentif guru ngaji sesuai dengan yang dijelaskan oleh Mukarom (2015: 205) dalam bukunya yang berjudul Manajemen Public relations Startegi Menjadi Humas Profesional. Menurutnya, menetapkan sasaran merupakan langkah yang dilakukan agar program berjalan tepat pada tujuannya. Penetapan khalayak sasaran penting untuk mengetahui khalayak mana saja yang harus mendapatkan informasi tentang sosialisasi program yang dilaksanakan.

Sasaran sosialisasi harus ditetapkan dengan tepat berdasarkan hasil dari pengumpulan data dan fakta pada tahap pertama (fact finding). Mukarom (2015: 206) memaparkan tidak tepat menentukan sasaran akan berdampak buruk seperti memperburuk keadaan bahkan mengakibatkan kerugian secara finansial. Hal ini yang dilakukan oleh Disdik, data dan fakta mengenai kondisi di lapangan kemudian diolah dan dijadikan acuan ketika menentukan target atau sasaran sosialisasi pada tahap perencanaan ini.

Keempat, menyusun anggaran merupakan pekerjaan yang penting dalam kegiatan perencaan program. Berdasarkan hasil temuan di lapangan yang didapatkan melalui wawancara kepada tiga orang informan tentang langkah 
menetapkan anggaran sosialisasi program. Didapatkan hasil bahwa anggaran program insentif guru ngaji berdasarkan dokumen pelaksanaan anggaran (DPA) pada pendidikan non formal Disdik Cimahi. DPA tersebut disesuaikan dengan kemampuan APBD kota Cimahi.

Anggaran pemberian insentif guru ngaji pada DPA ini dianggarakan untuk seluruh kebutuhan dan kegiatan yang ada program tersebut, termasuk anggaran untuk kegiatan sosialisasi. Anggaran untuk kegiatan sosialisasi dan kegiatan lainnya, selain penyaluran dana insentif kepada guru ngaji ditekan seefektif mungkin. Hal ini dilakukan karena Disdik ingin memberikan insentif dengan jumlah semaksimal mungkin kepada para guru ngaji.

Berdasarkan pemaparan di atas, penetapan anggaran sosialisasi program insentif guru ngaji merupakan bagian penting dalam perencaan sosialisasi program. Sesuai dengan yang dinyatakan oleh Morissan (2018: 179) dalam bukunya yang berjudul Manajemen Public relations Startegi Menjadi Humas Profesional. Menurutnya, menyusun anggaran merupakan salah satu pekerjaan penting yang harus dilakukan pada tahap perencanaan program. Dana dianggarkan agar terbentuknya kedisiplinan penggunaan dana dan mencegah pemborosan dana, yang digunakan untuk hal-hal tidak perlu atau untuk hal-hal yang berlebihan.

Melalui anggaran, dapat diketahui hal-hal apa saja yang harus dikerjakan dan apa saja yang tidak bisa dikerjakan sesuai dengan sumber daya yang dimiliki, demikian yang dijelaskan oleh Morissan (2018: 179). Hal ini selaras dengan yang dilakukan oleh Disdik pada program pemberian insentif guru ngaji. Salah satunya yaitu penganggaran yang dimaksimalkan untuk insentif yang diberikan kepada para guru ngaji. Anggaran dana untuk kebutuhan dan kegiatan lainnya dibuat seminim mungkin, namun tetap dengan usaha dan sumber daya lainnya yang dimaksimalkan. Dapat dilihat Disdik menganggarkan dana dan bahkan sumber daya lainnya sesuai dengan kemampuan dan kebutuhan.

\section{Tahap Bertindak dan Berkomunikasi}

Bertindak dan berkomunikasi merupakan tahap yang ditempuh setelah mencari fakta dan menyusun rencana. Seperti yang dijelaskan oleh Morissan (2018: 152) dalam bukunya yang berjudul Manajemen Public relations Strategi menjadi Humas Profesional. Menurutnya, tahap ketiga yang harus ditempuh dalam manajemen public relations yakni implementasi program public relations. Adapun implementasi merupakan proses untuk memastikan terlaksananya suatu program sesuai dengan perencanaan yang telah dibuat sebelumnya.

Implementasi program public relations berarti keputusan terhadap tindakan komunikasi yang akan dilakukan berdasarkan data dan rencana yang telah dibuat pada tahap-tahap sebelumnya. Keputusan dan tindakan yang diambil pada tahap ini berupa kegiatan-kegiatan komunikasi. Menurut Mukarom (2015: 
218), keberhasilan komunikasi ditentukan oleh kredibilitas komunikator, kejelasan isi pesan, kemampuan komunikan, keterkaitan antara komunikator dengan komunikan, dan pemilihan serta penggunaan saluran/media dalam menyampaikan pesan.

Kegiatan pada tahap bertindak dan berkomunikasi ini merupakan tindakan yang menyangkut operasional dan teknis. Menurut Sulistyaningtyas (2010: 180) dalam jurnalnya yang berjudul Riset sebagai Ujung Tombak Keberhasilan Program Public relations, pada tahap ketiga ini PR akan dihadapkan langsung dengan publiknya sehingga diperlukan teknik kehumasan. PR dituntut untuk memahami teknik-teknik PR sesuai dengan salah satu perannya yakni sebagai teknisi komunikasi. Teknik PR tersebut diantaranya memahami dan menguasai public relations writing, public speaking, berhubungan dengan media, serta berhubungan dengan publik internal dan eksternal lainnya.

Berdasarkan hasil temuan di lapangan dengan mewawancari tiga informan, terdapat tiga tindakan komunikasi yang diambil oleh Disdik pada tahap ini, sebagai berikut:

Pertama, menentukan sifat komunikasi yang dipilih dalam kegiatan sosialisasi. Komunikasi merupakan suatu proses penyampaian ide, gagasan, pikiran dan atau perasaan seseorang kepada orang lain. Komunikasi memiliki beberapa sifat yakni komunikasi verbal baik secara lisan maupun tulisan, komunikasi non verbal, komunikasi tatap muka dan komunikasi bermedia. Selain sifat komunikasi, harus ditentukan juga tatanan komunikasi yang akan digunakan, apakah menggunakan komunikasi antarpribadi, komunikasi massa atau komunikasi kelompok.

Hasil temuan di lapangan, Disdik Cimahi mensosialisasikan program insentif guru ngaji ini melalui dua cara. Pertama, sosialisasi dilakukan secara langsung tatap muka, guru ngaji se-kota Cimahi diundang untuk menghadiri acara sosialisasi. Kedua, sosialisasi lanjutan yang dilaksanakan secara daring (dalam jaringan). Disdik menugaskan seorang koordinator di setiap kelurahan untuk mengkoordinir guru ngaji dan menjadi jembatan informasi dari Disdik kepada guru ngaji atau sebaliknya. Koordinator bertugas untuk menyampaikan berbagai informasi dari Disdik dan mengingatkan guru ngaji untuk melaksanakan kewajibannya. Koordinator juga bertugas menginformasikan apabila sudah ada pencairan dana.

Sosialisasi secara langsung tatap muka merupakan komunikasi dengan sifat komunikasi verbal secara lisan, karena penyampaian pesan komunikasi disampaikan kepada khalayak secara lisan. Bentuk sosialisasi yang kedua yakni komunikasi melalui grup whatsapp yang dikoordinir oleh seorang koordinator dari Disdik Cimahi. Sosialisasi ini merupakan komunikasi bermedia karena menggunakan media kedua setelah bahasa sebagai media pertama dalam berkomunikasi. 
Sosialisasi pemberian insentif guru ngaji baik secara langsung tatap muka maupun secara daring termasuk ke dalam tatanan komunikasi kelompok. Tatanan komunikasi menurut Effendy (2003: 53) adalah proses komunikasi yang ditinjau dari jumlah kelompoknya. Komunikasi kelompok berarti komunikasi yang berlangsung antara seorang komunikator dengan sekelompok orang yang jumlahnya lebih dari dua orang. Kegiatan sosialisasi program insentif guru ngaji memiliki komunikan lebih dari dua orang.

Sosialisasi yang dilakukan oleh Disdik ini termasuk ke dalam komunikasi kelompok kecil, meskipun jumlah khalayak sosialisasinya sangat banyak. Karena kembali lagi seperti yang diungkapkan oleh Effendy (2003: 76) bahwa yang membedakan komunikasi kelompok kecil dengan kelompok besar bukan jumlah komunikannya yang dihitung secara matematis tetapi pada proses komunikasinya.

Sifat dan tatanan komunikasi pada sosialisasi pemberian insentif guru ngaji telah ditentukan, selanjutnya yaitu memilih jenis komunikasi apa yang dipilih untuk mendukung sosialisasi yang dilakukan secara langsung tatap muka dan secara daring. Jenis komunikasi yang akan dibahas disini yakni jenis komunikasi tertulis. Hasil temuan di lapangan, Disdik menyusun suatu buku panduan khusus tentang program pendidikan keagamaan yang di dalamnya termasuk program pemberian insentif guru ngaji. Buku panduan yang dibuat oleh Disdik ini termasuk ke dalam jenis buku organisasi atau jenis buku yang diterbitkan oleh internal organisasi.

Tindakan komunikasi yang diambil oleh Disdik Cimahi pada langkah ini yakni menentukan sifat tatanan dan jenis komunikasi yang digunakan agar sosialisasi dapat terlaksana dengan baik mencapai tujuan yang telah dicanangkan. Berdasarkan hal tersebut, pada langkah ini Disdik telah melakukan strategi tindakan komunikasi sesuai dengan langkah dalam tahap bertindak dan berkomunikasi pada pada konsep four steps public relations.

Kedua, menyusun pesan sosialisasi. Sosialisasi merupakan kegiatan komunikasi, komponen dalam sosialisasi tentu sama dengan komponen komunikasi. Komponen ini yang berusaha dikelola dengan baik sesuai dengan langkah penyusunan komponen strategi komunikasi agar sosialisasi dapat berjalan dengan minim hambatan dan dapat mencapai tujuan seperti yang diharapkan. Setelah sebelumnya Disdik menyusun tim khusus untuk mengetahui karakteristik dan latar belakang komunikan, selanjutnya yakni mengelola pesan yang akan disampaikan.

Berdasarkan hasil temuan di lapangan dengan mewawancarai tiga orang informan, Disdik mempersiapkan pesan sosialisasi dan menyusunnya dengan baik sebelum melaksanakan sosialisasi. Seperti yang dilakukan oleh Kasi Dikmas, sebelum menjadi narasumber utama dalam kegiatan sosialisasi. Kasi Dikmas 
membuat power point yang menarik. Hasil temuan tersebut selaras dengan yang diungkapkan oleh Suryanto (2015: 177) dalam bukunya yang berjudul Pengantar Ilmu Komunikasi. Menurutnya, pesan yang akan disampaikan harus disiapkan dengan baik dan sesuai dengan tujuan yang ingin dicapai.

Menyiapkan pesan sosialisasi dengan baik dan sesuai dengan tujuan yang ingin dicapai merupakan satu langkah penting yang harus dilakukan mengingat pesan juga merupakan unsur komunikasi yang sangat krusial. Disdik membuat draf sambutan yang untuk Wali Kota dan Kepala Dinas yang juga menjadi komunikator dalam kegiatan sosialisai. Hal ini dilakukan agar pesan sosialisasi yang ingin disampaikan oleh masing-masing komunikator tetap tersampaikan, meskipun penyampaian pesan secara panjang lebar.

Draf sambutan juga dikemas dengan penyampaian yang edukatif tentang pentingnya pendidikan keagamaan dan mempersuasi khalayak untuk bersikap dan berpartisipasi sesuai dengan yang diharapkan. Hal ini sesuai dengan strategi humas dalam sosialisasi yang diungkapkan oleh Widjaja (2010: 60) dalam bukunya yang berjudul Komunikasi dan Hubungan Masyarakat.

Pesan-pesan sosialisasi yang disampaikan oleh komunikator kemudian dituangkan ke dalam satu buku panduan khusus. Buku ini disusun dengan pertimbangan karena ketika sosialisasi tidak semua peserta sosialisasi dapat menyerap dan mengingat hal-hal pentingnya. Buku disusun dengan penyampaian yang menarik dan sederhana agar mudah dipahami oleh pembacanya, menyesuaikan dengan latar belakang dan karakteristik dari sasaran sosialisasi. Harapannya buku ini dapat memberikan informasi tentang program dan dapat mempersuasi sasaran dalam bersikap dan mendukung program sesuai dengan yang diharapkan.

Berdasarkan pemaparan di atas, mengenai penyusunan pesan sebagai komponen komunikasi, Disdik Cimahi telah menyusun pesan agar dapat disebarkan dan diterima dengan baik oleh sasaran. Langkah yang ditempuh oleh Disdik dalam menyusun pesan ini sesuai dengan penyusunan pesan sebagai komponen strategi komunikasi pada tahap bertindak dan berkomunikasi dalam konsep four steps public relations.

Ketiga, menentukan komunikator sosialisasi. Elemen atau komponen komunikasi yang harus disiapkan sebelum sosialisasi yakni komunikator (penyampai pesan). Komunikator berperan penting pada proses penyebaran pesan yang telah disusun sebelumnya, Menurut Morissan (2018: 203) komunikator harus mampu menyampaikan pesan tersebut dengan bahasa yang mudah dipahami dan dimengerti oleh komunikan. Berdasarkan hasil temuan di lapangan, Disdik memilih komunikator menyesuaikan dengan pesan yang ingin disampaikan dengan kredibilitas yang dimiliki oleh komunikator.

Pesan yang disampaikan pada kegiatan sosialisasi yakni agar program 
insentif guru ngaji dapat terlaksana dengan baik tepat pada sasarannya dan tujuan program dapat tercapai. Tujuan program ini merupakan bentuk perhatian dan apresiasi dari pemerintah dalam hal ini Wali Kota, terhadap guru ngaji dengan dituangkan pada program prioritas di masa pemerintahannya. Wali kota juga memiliki visi Agamis yang kemudian dikembangkan pada program ini. Berdasarkan hal itu, Disdik memilih Wali Kota sebagai salah satu komunikator dalam kegiatan sosialisasi karena merupakan pemilik dan yang menjanjikan adanya program ini. Wali kota menyampaikan apresiasimya kepada guru ngaji serta menyampaikan pentingnya program ini dalam mewujudkan visi Cimahi Agamis.

Komunikator lainnya yang mengisi dalam kegiatan sosialisai adalah Kepala Dinas Pendidikan Kota Cimahi. Disdik ditugaskan oleh Wali Kota dalam mengelola program pemberian insentif guru ngaji, secara otomatis Kadisdik yang bertanggung jawab atas kegiatan sosialisasi. Kadisdik sebagai komunikator sosialisasi menyampaikan informasi mengenai program ini dari segi administrasinya, seperti landasan hukum yang menjadi payung hukum program sampai dengan asal usul penganggaran dana serta jumlah dana yang dianggarkan.

Komunikator utama yakni Kasi Dikmas yang menyampaikan hak dan kewajiban yang harus dipenuhi oleh guru ngaji serta mekanisme pencairan dana. Seksi Dikmas merupakan bagian yang ditugaskan oleh Kadisdik untuk merumuskan mengelola dan melaksanakan program ini. Seksi Dikmas yang merancang rangkaian kegiatan program insentif guru ngaji tentu berada di bawah binaan dan arahan Kadisdik juga Wali Kota. Kasi Dikmas menegaskan kembali yang disampaikan oleh Wali Kota dan Kadisdik, setelah itu menyampaikan detail-detail programnya.

Sosialisasi program insentif guru ngaji tidak hanya dilakukan secara langsung tatap muka saja tetapi juga melalui online di grup WhatsApp. Adapun yang menjadi komunikator pada sosialisasi secara daring ini adalah koordinator yang ditugaskan di setiap kelurahan. Koordinator tersebut yang mengkoordinir guru ngaji di setiap kelurahan juga sebagai jembatan informasi dari Disdik kepada Lurah, RW dan guru ngaji secara langsung.

Komunikator sosialisasi di atas memiliki kredibilitas yang sesuai dengan pesan yang akan disampaikan. Selaras dengan yang diungkapkan oleh Suryanto (2015: 161) komunikator adalah penyampai pesan. Komunikator hendaknya menguasai informasi yang akan disebarkan kepada komunikannya. Komunikator juga hendaknya memiliki kredibilitas terhadap pesan yang disampaikan olehnya serta dikenal kredibilitas dan otoritasnya tersebut oleh komunikan. Hal ini penting karena akan memengaruhi komunikan dalam menerima dan terpengaruh oleh pesan sosialisasi.

Disdik memiliki tiga orang komunikator pada kegiatan sosialisasi. 
Komunikator dipilih sesuai dengan pesan yang ingin disampaikan dan kredibilitas serta otoritas yang dimiliki oleh masing-masing komunikator. Disidik memilih komunikator sebagai penyebar pesan dalam komponen strategi komunikasi pada tahap bertindak dan berkomunikasi konsep manajemen public relations.

Berdasarkan hasil pembahasan Disdik Cimahi melakukan tahap bertindak dan berkomunikasi sesuai dengan konsep four steps public relations. Disdik mengambil strategi tindakan komunikasi dengan menentukan sifat, tatanan dan jenis komunikasi. Menyiapkan komponen komunikasi yakni menyusun pesan sosialisasi dan menentukan komunikator sosialisasi.

Tahap Evaluasi

Evaluasi program merupakan tahap terakhir dalam manajemen public relations. Evaluasi program public relations merupakan penilaian terhadap tindakan komunikasi yang dijalankan dengan perencanaan yang telah dirumuskan. Pada tahap ini pengumpulan informasi dilakukan terkait tahaptahap manajemen public relations yang telah dilalui kemudian dianalisis secara sistematis dan objektif. Hasil dari analisis tersebut yakni peniliain terhadap keberhasilan pelaksanaan program.

Disdik Cimahi melakukan evaluasi pada sosialisasi program pemberian insentif guru ngaji karena evaluasi ini sangat penting bagi keberlangsungan program. Evaluasi tentu menghasilkan simpulan dari keberhasilan program public relations dalam hal ini kegiatan sosialisasi. Keberhasilan program public relations menurut Mukarom (2015: 242) dilihat dari berbagai hal. Pertama, keberhasilan program PR dapat dilihat dari penghargaan, pujian dan liputan oleh media massa. Keberhasilan lainnya dilihat dari hasil pengukuran secara ilmiah terhadap perubahan pengetahuan, pendapat, sikap dan tingkah laku khalayak sebelum dan sesudah dilaksanakannya program PR.

Berdasarkan hasil temuan di lapangan, Disdik melakukan evaluasi dari tujuan yang telah ditetapkan dengan respon dari guru ngaji dan masyarakat. Disdik melihat keberhasilan sosialisasi program insentif guru ngaji dari dua hal. Pertama, dengan melakukan pengamatan secara langsung di lapangan oleh tim khusus yang sudah bertugas sejak awal sebelum dilakukan sosialisasi program. Kedua, evaluasi dilakukan dengan melihat laporan bulanan yang dikirimkan oleh guru ngaji.

Dua indikator evaluasi yang dilakukan oleh Disdik ini mengacu pada tujuan yang telah ditetapkan sebelumnya. Adanya sosialisasi yakni agar tujuan dari program insentif guru ngaji tersampaikan dengan baik serta dampaknya dapat diaplikasikan dalam kehidupan sehari-hari. Tujuan programnya yakni mewujudkan visi Cimahi Agamis melalui membudayakan magrib mengaji. Ini yang diamati oleh tim di lapangan sebelum dan setelah dilaksanakan sosialisasi. Pesan yang disampaikan ketika sosialisasi yakni kewajiban guru ngaji untuk 
mengumpulkan laporan berisi rencana pembelajaran dan dokumentasi mengajarnya.

Hasil temuan tersebut sesuai dengan evaluasi tahap efek pada tahap evaluasi manajemen public relations. Seperti yang diungkapkan oleh Morissan (2018: 153) evaluasi dilakukan pada tiga tingkatan yakni persiapan, pelaksanaan dan efek atau dampak. Selaras dengan Mukarom (2015: 246) yang menjelaskan bahwa evaluasi dilakukan pada tiga tingkatan dengan aspek penilaian yang berbeda-beda. Evaluasi tahap persiapan memberikan penilaian atas kualitas informasi dan kecukupan informasi serta perencanaan yang dilakukan. Evaluasi tahap implementasi menilai kelengkapan taktik dan cukupan usaha yang dilakukan. Terkahir, evaluasi tahap efek memberikan penilaian atas efek yang dihasilkan dari suatu program public relations yang dilaksanakan.

Disdik Cimahi melakukan evaluasi hanya pada tahap efek saja, seperti yang dipaparkan pada paragraf sebelumnya. Disdik mengamati dan menilai perbedaan di lapangan sebelum dan setelah dilakukan sosialisasi program. Hal ini selaras dengan yang diungkapkan oleh Mukarom (2015: 242) bahwa evaluasi terhadap keberhasilan program dapat dilihat dari hasil pengukuran secara ilmiah terhadap perubahan pengetahuan, pendapat, sikap dan tingkah laku khalayak sebelum dan sesudah dilaksanakannya program PR.

Berdasarkan hasil wawancara, terdapat perubahan yang cukup baik pada sosialisasi yang dilakukan di tahun 2019, setelah adanya sosialisasi, guru ngaji beserta masyarakat mendukung tujuan-tujuan program yang diharapkan oleh pemerintah. Selain dengan mengamati secara langsung di lapangan, Disdik melakukan evaluasi dengan melihat laporan yang dikirimkan oleh guru ngaji. Hasil evaluasi di tahun 2019 sudah cukup banyak guru ngaji yang memenuhi kewajibannya untuk mengumpulkan laporan sesuai dengan format yang diberikan, meskipun masih belum 100\% mengumpulkan.

Berdasarkan pembahasan di atas Disdik Cimahi telah menempuh tahap evaluasi sesuai dengan tahap evaluasi pada konsep four steps public relations. Evaluasi yang dilakukan oleh Disdik pada sosialisasi program pemberian insentif guru ngaji dilakukan pada evaluasi tahap efek/dampak. Disdik melakukan evaluasi terhadap pencapaian tujuan yang telah direncanakan dengan tujuan yang telah dicapai. Evaluasi tersebut pada perubahan sikap, perilaku dan tindakan pada sasaran sebelum dan setelah dilaksanakan sosialisasi program tersebut.

\section{PENUTUP}

Berdasarkan hasil penelitian, disimpulkan bahwa Dinas Pendidikan Kota Cimahi telah melakukan manajemen sosialisasi Program Pemberian Insentif Guru Ngaji sesuai dengan tahapan dalam konsep manajemen public relations (four steps public relations). Pertama,tahap pencarian data (fact finding) sebagai tahap awal 
yang dilakukan Disdik Cimahi untuk memahami program yang akan disosialisasikan serta latar belakang dan karakteristik khalayak program.

Kedua, tahap perencanaan dalam sosialisasi program pemberian insentif guru ngaji bertujuan untuk memaksimalkan sumber daya yang dimiliki oleh Disdik Cimahi. Langkahnya dimulai dengan penetapan tujuan dan target sosialisasi, membuat acuan kerja hingga penganggaran dana. Ketiga,Tahap bertindak dan berkomunikasi yang dilakukan Disdik Cimahi dalam sosialisasi yaitu dengan menentukan bentuk komunikasi, menyusun pesan sosialisasi dan menentukan komunikator sosialisasi. Keempat, Tahap evaluasi yang dilakukan oleh Disdik bertujuan untuk mengukur ketercapaian tujuan sosialisasi. Evaluasi dilihat dari dua indikator yaitu laporan yang dikumpulkan oleh guru ngaji serta perubahan sikap khalayak yang dipantau secara langsung di lapangan.

\section{DAFTAR PUSTAKA}

Effendy, Onong Uchjana. (2003). Hubungan Masyarakat; Suatu Studi Komunikasi. Bandung: Remaja Rosdakarya.

Hasan, Erliana. (2010). Komunikasi Pemerintahan. Jakarta: Universitas Terbuka. Hasybullah, M. Alfian. (2019). Manajemen Special Event Upacara Adat Seren Taun Cigugur Kuningan dalam Communicatus: Jurnal Ilmu Komunikasi, 2(1), 53-68.

Maryamah. (2019). Sosialisasi Program "Kangpisman” Oleh Bidang Humas Pemerintah Kota Bandung Dalam Upaya Bandung Bersih. Skripsi, Jurusan Ilmu Hubungan Masyarakat, UIN Sunan Gunung Djati Bandung.

Morissan. (2014). Manajemen Public relations. Jakarta: Kencana.

Mukarom, Zainal. dkk. (2015). Manajemen Public relations (Panduan Efektif Pengelolaan Hubungan Masyarakat. Bandung: Pustaka Setia.

Patmawati, Ika Sari. (2016). Sosialisasi Program Keluarga Berencana Oleh Pusat

Kesehatan Desa dengan Pendekatan Komunikasi Interpersonal di Desa Jemparing Kecamatan Long Ikis Kabupatan Paser dalam Jurnal Komunikasi, 4(1), 1-14.

Putri, Ridha Utama. dkk. (2018). Manajemen Humas dalam Program Pemberian

Penghargaan bagi Karyawan dalam Reputation: Jurnal Ilmu Hubungan Masyarakat, 3(2), 58-69.

Sulistyaningtyas, Ike Devi. (2010). Riset sebagai Ujung Tombak Keberhasilan

Program Public relations dalam Jurnal Ilmu Komunikasi, 7(2), 171-186.

Suryanto. (2015). Pengantar Ilmu Komunikasi. Bandung: Pustaka Setia.

Website Kota Cimahi. Melalui < https://cimahikota.go.id/>

Widjaja, H. (2010). Komunikasi dan Hubungan Masyarakat. Jakarta: Bumi Aksara. 